\title{
Morphometric Characterization of Attalea maripa (Arecaceae) from Roraima State, Brazil
}

\author{
Mahedy A. B. Passos ${ }^{1}$, Otoniel R. Duarte ${ }^{2} \&$ Kaoru Yuyama ${ }^{3}$ \\ ${ }^{1}$ Instituto Nacional de Pesquisas da Amazônia, Programa de Pós-Graduação em Botânica, Manaus, Amazonas, \\ Brazil \\ ${ }^{2}$ Empresa Brasileira de Pesquisa Agropecuária, Boa Vista, Roraima, Brazil \\ ${ }^{3}$ Instituto Nacional de Pesquisas da Amazônia, Programa de Pós-Graduação em Botânica, Manaus, Amazonas, \\ Brazil \\ Correspondence: Mahedy A. B. Passos, Instituto Nacional de Pesquisas da Amazônia. Programa de \\ Pós-Graduação em Botânica, Av. André Araujo, 2.936, Petrópolis, Caixa Postal: 2223, 69080-971, Manaus, \\ Amazonas, Brazil. E-mail: mahedypassos@hotmail.com
}

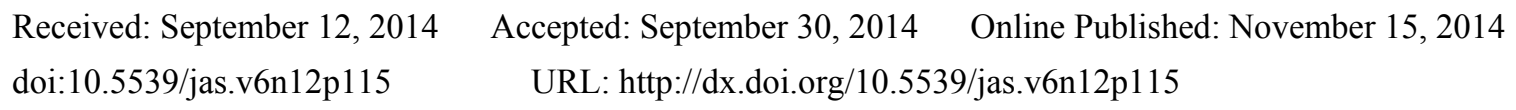

\begin{abstract}
We characterized three different morphotypes of inajá (Attalea maripa (Aublet.) Mart.) based on the stipe foliar insertion: columnar (morphotype M1), semi-spiraled (morphotype M2) and spiraled (morphotype M3) insertion. The present study quantified the number of leaves, the production of bunches and the DBH of the matrices and made morphometric analyses of the fruits and morphological characterization of the seedlings, for each morphotype. Bunches bearing A. maripa fruits, originating from natural regeneration, were collected from silvopastoral systems distributed throughout six counties of the state of Roraima, in order to study their morphometry. Four replicates of twenty diaspores were sown according to the Seed Analysis Rules, for seedling morphology study. The semi-spiraled morphotype presented the highest values of size and weight of fruits and seeds (diaspores). Morphotype M2 is likely to be an intermediate form of a widely variable character within $A$. maripa. The most frequent inflorescences amongst the studied morphotypes showed to be predominantly female, androgynous and predominantly male inflorescences were also found along with more than one type of inflorescence per individual. There is a wide variability as to the coloring of the fruits regardless of their origin. Attalea maripa seedlings did not present the typical characteristics described for the genus Attalea.
\end{abstract}

Keywords: morphometry, foliar insertion, morphology, palm tree, morphotypes

\section{Introduction}

Morphological studies regarding Amazonian palm trees are important to achieve a better understanding of the species vegetative cycle. Furthermore, investigations on taxonomy, ecology and propagation of species enable the elaboration of products such as palm hearts, fruits and oils, as a way of innovating the market and strengthening the Amazonian economy (Araújo, Leitão, \& Mendonça, 2000; Gentil \& Ferreira, 2005).

Amongst the species with potential economic value, Attalea maripa (Aublet) Mart., a palm tree popularly known as inajá which establishes well in anthropized environments and soils with low fertility, stands out. The mesocarp of its fruits may be used fresh for consumption by humans or wild animals such as birds, monkeys, small rodents (Ferreira, 2005) and South American anteaters (personal observation). From its growing buds near the apical meristem, palm heart of exceptional flavor and quality is extracted and utilized by inland communities of Roraima for preparing hot dishes. From its fruit kernel and mesocarp, an oil of great utility in food, cosmetic and soap industries is extracted. It is also used in the production of bio-fuels (Bezerra, 2011; Miranda et al., 2001; Pereira et al., 2013).

In Roraima, A. maripa is considered an invasive plant, presenting vigorous regeneration and, even after intense fires, it is possible to observe dense populations in anthropized areas, pastures and transition areas between forests and savannahs of the region, with a mean density of 92 adult plants in productive phase per hectare (Duarte, 2008).

Investigations in secondary forest fragments and primary forests showed $A$. maripa plays an important role on 
canopy height and density recovery, corroborating the hypothesis that perturbation is important for its recruitment (Salm, 2005). Thus, A. maripa may also be an alternative for the recovery of deforested areas. According to Ferreira (2005), the management of this species natural populations in pasture areas aiming to improve their density may be undertaken without the need of high financial investments.

Attalea maripa presents a wide variability regarding its vegetative characteristics, like foliar insertion, fruit coloring, shape and size, with some information diverging between authors, possibly due to the lack of studies regarding the comparison between species populations in different regions.

Researches on morphological and morphometric aspects that characterize A. maripa offer important information for the propagation of the species, helping on the selection of matrices and the harvest of bunches with higher oil production potential. Furthermore, literature shows no works that identify different morphotypes, which may encourage studies on phenology, improvement and management seeking to incorporate A. maripa into fruit production systems. It is important to emphasize that without a previous knowledge of such characteristics, there is no possibility of developing techniques that would enable the domestication and consequent commercial exploitation of this species.

Within this context, the present work aims to characterize the morphotypes of the matrices and the morphology of post-seminal development of $A$. maripa seedlings, in order to provide information for the development and expansion of techniques that will promote new ways of utilization and commercialization of its products and byproducts.

\section{Materials and Methods}

The identification of the plants for the characterization of the morphotypes was conducted between March 2011 and September 2013 with 70 individuals (matrices) of the inajá Germplasm Active Bank (GAB) of Embrapa Roraima, Brazil, originating from natural regeneration and randomly distributed throughout Iracema, Mucajaí, Cantá, Alto Alegre, Caracaraí and Boa Vista Counties silvopastoral systems.

According to Köppen (1984), these regions climates are of Awi/Ami types, tropical humid, with a rainy season from April to August, with mean annual precipitation of 2,000 $\mathrm{mm}$ and mean annual temperatures between $28^{\circ} \mathrm{C}$ and $38^{\circ} \mathrm{C}$.

Generally, inajá is a single stem palm, reaching approximately $25 \mathrm{~m}$ in height and $40 \mathrm{~cm}$ in diameter (Miranda \& Rabelo, 2006). It presents an assemblage of leaves on the apex of the stipe, inserted in a spiraled way or in five vertical rows, its leaves present linear, erect pinnae, grouped and arranged at different angles, giving the leaves a feathery look (Henderson, Galeano, \& Rodrigues, 1995; Ribeiro et al., 1999; Lorenzi, 2010). Inflorescence is described as intra or inter-foliar (Cravo, 1998; Duarte, 2008; Matos, 2010; Miranda et al., 2001). Fruits are ovoid (Araújo et al., 2000) or oblong ellipsoid shaped, smooth and varyingly sized. The coloring of the fruits varies from yellow to brown when ripe with oily mesocarp, ranging from light beige to yellow. The endocarp, totally adhered to the seed tegument, presents septa originated from unilocular, bilocular or trilocular ovary, forming fruits with one, two or three kernels (Kahn, 1990; Cavalcante, 1991; Henderson et al., 1995; Araújo et al., 2000; Miranda et al., 2001).

For the characterization of the morphotypes, data was obtained regarding the foliar arrangement, number of bunches, type of inflorescence and diameter of the stipe. The diameter at breast height (DBH) of the stipe was measured at $50 \mathrm{~cm}$ from the ground with a measuring tape, on account of some of the matrices in the fructification stage still have a sheath in the basal part of the plant. The inajá bunches were collected by hand, with a $3 \mathrm{~m}$ long stick and a scythe.

Following the collection, the bunches were taken to the Residue Laboratory at the headquarters of Embrapa/RR, for later morphometric characterization of the fruits, which was performed by utilizing thirty ripe fruits from a bunch of each access out of a total of 70 .

We measured fruit length, diameter and weight, one by one, for their physical characterization with the aid of Digimess digital caliper and a model JH2102 BIOPRECISA precision scale. We described their inner and outer characteristics, such as the shell and mesocarp coloring. We took one random sample out of 100 diaspores to tally the number of kernels per diaspore. A nutcracker had to be used to break the fruit stones.

For the seedling characterization, we sowed four replicates of twenty seeds with no mesocarp, totaling 80 seeds. We sowed the seeds in garden beds with sand as a substrate, kept in a greenhouse and watered daily, following the recommendations of the Seed Analysis Rules (Ministério da Agricultura [Brazil], 1992). We conducted the morphological characterization of the seedlings, following their complete establishment, adopting the terminology used by Kerbauy (2008). 
We analyzed the variables by using Analysis of Variance (ANOVA) and the means were compared by the Tukey test at $5 \%$ level of probability. We used the Pearson Correlation to test the correlation between the weight, length and diameter of the fruits. We conducted all statistical analyses by utilizing the Statistics Computer Program.

\section{Results}

\subsection{Seedling Morphology of Attalea maripa}

The emergence of the A. maripa seedling is hypogeal cryptocotyledonary. The cotyledon petiole is cylindrical and whitish, emerging through the operculum, maintaining the seed below ground level and the cotyledon limb inside the seed.

Following the emission of the cotyledon petiole, the primary root, the first secondary roots, the sheaths and the first eophyll arise. The emergence of the first eophyll begins with the arising of the erect leaf above ground level, completely green, whole and lanceolate with smooth upper margin, pointy, whitish and symmetric apex (Figure 1). The seedling still remains attached to the diaspore for a long time.

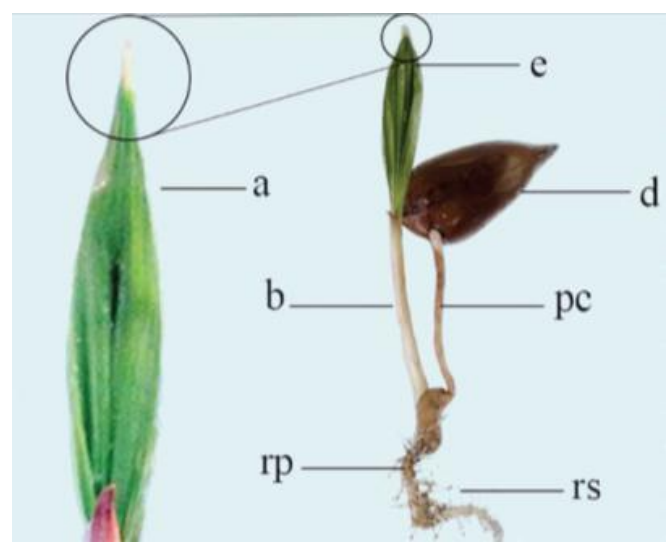

Figure 1. Seedling of A. maripa. Plant structures: a- apex, b- sheath, e- eophyll, d- diaspore, pc- cotyledon petiole, rp- primary root, rs- secondary root

\subsection{Inajá Morphotypes Characterization}

\subsubsection{Morphotype M1}

Foliar insertion on the stem: Columnar (leaves inserted with wholly overlapped foliar bases forming vertical columns) (Figure 2A). Number of leaves: 17-33 (mean: 23.25 leaves). Foliar segments: arranged in regular or irregular planes and distributed individually or grouped in 2, 3, 4 or 5 pinnae in one leaf. DBH: $75-157 \mathrm{~cm}$ (mean: $103.09 \mathrm{~cm}$ ). Number of bunches: 1-4 (mean: 2.37). Inflorescence type: androgynous, predominantly female or predominantly male with a higher frequency of predominantly female bunches. Fruit length: 39.93-61.91 mm (mean: $48.02 \mathrm{~mm}$ ). Fruit diameter: 23.35-34.9 mm (mean: $29.04 \mathrm{~mm}$ ). Fruit weight: 13.48-26.26 g (mean: $19.67 \mathrm{~g}$ ). Seed weight: 7.25-12.66 g (mean: $9.63 \mathrm{~g}$ ). Fruit color varies from light-brown to brown, with a ferruginous tegument, rarely green with ferruginous tegument. Fruit mesocarp color ranges from beige to orange, including light-yellow and yellow. Flavor: saponaceous, rarely sweet.

\subsubsection{Morphotype M2}

Foliar insertion into the stem: semi-spiraled (leaves inserted with barely overlapped foliar bases forming a slightly curved column in their median portion) (Figure 2B). Number of leaves: 14-30 (mean: 21.84 leaves). Foliar segments: arranged in regular or irregular planes and distributed individually or grouped in 2, 3, 4 or 5 pinnae in one same leaf. DBH: $68-155 \mathrm{~cm}$ (mean: $109.06 \mathrm{~cm}$ ). Number of bunches: 1-5 (mean: 2.75 bunches). Type of inflorescence: androgynous, predominantly female or predominantly male with predominance on androgynous or predominantly female inflorescences. Fruit length: 38.28-61.73 mm (mean: $47.85 \mathrm{~mm}$ ). Fruit diameter: 25.39-35.77 mm (mean: $30.41 \mathrm{~mm}$ ). Fruit weight: 15.36-36.63 g (mean: $22.39 \mathrm{~g}$ ). Seed weight: 7.41-17.33 g (mean: $11.21 \mathrm{~g}$ ). Fruit coloring: varying from light green to yellow to dark brown. Fruit mesocarp color: ranging from white to orange including beige and yellow. Flavor: varying from slightly saponaceous to sweet. 


\subsubsection{Morphotype M3}

Foliar insertion into the stem: Spiraled (leaves inserted with slightly or not overlapped bases forming a spiral) (Figure 2C). Number of leaves: 19-30 (mean: 25.04 leaves). Foliar segments: arranged in regular or irregular planes and distributed individually or grouped in 2, 3, 4 or 5 pinnae in one leaf. DBH: 82-124 cm (mean: 99.71 $\mathrm{cm})$. Number of bunches: 1-4. Type of inflorescence: androgynous, predominantly male and predominantly female with predominance of predominantly female inflorescences. Fruit length: $37.62-54.88 \mathrm{~cm}$ (mean: 45.49 $\mathrm{cm}$ ). Fruit diameter: $23.25-33.18 \mathrm{~mm}$ (mean: $28.07 \mathrm{~mm}$ ). Fruit weight: 13.28-23.63 g (mean: $18.56 \mathrm{~g}$ ). Seed weight: $6.86-12.01 \mathrm{~g}$ (mean: $9.22 \mathrm{~g}$ ). Fruit coloring: varying from light-green to dark-brown with a predominance of the brown shades. Fruit pulp color: varying from beige to orange with a yellow predominance. Flavor: slightly saponaceous and rarely sweet.

In the morphotypes identified in the present work, the maximum and minimum number of leaves reached 33 and 17 , respectively. In morphotypes M1 and M2 the mean number of leaves showed to be of approximately 23; whereas in morphotype M3, it remained close to 25 per individual. No significant statistical difference was found on the number of leaves between morphotypes M1 and M2 or morphotypes M1 and M3. However, we found a significant statistical difference between morphotypes M3 and M2 $(p=0.008)$ with M3 presenting 3.2 more leaves than morphotype M2 ( $\mathrm{p}=0.006)$ (Table 1).

Table 1. Mean of morphometric variables of the A. maripa morphotypes identified in Roraima

\begin{tabular}{cccccccc}
\hline & \multicolumn{7}{c}{ Morphometrics Variables } \\
\hline Morphotypes & NL & DBH & NB & FL & FD & FW & DW \\
\cline { 2 - 8 } Columnar (M1) & 23.25 & 32.83 & 2.37 & 48.03 & 29.04 & 19.67 & 9.63 \\
Semi-spiraled (M2) & 21.84 & 34.90 & 2.75 & 47.86 & 30.41 & 22.39 & 11.21 \\
Spiraled (M3) & 25.04 & 31.75 & 2.72 & 45.49 & 28.07 & 18.56 & 9.22
\end{tabular}

$\mathrm{NL}=\overline{\text { Number of leaves; DBH }=\text { Diameter }(\mathrm{cm}) \text { at } 50 \mathrm{~cm} \text { from the ground; NB = Number of bunches; FL }}=$ Fruit length (mm); FD = Fruit diameter (mm); FW = Fruit weight (g); DW = Diaspore weight (g). 

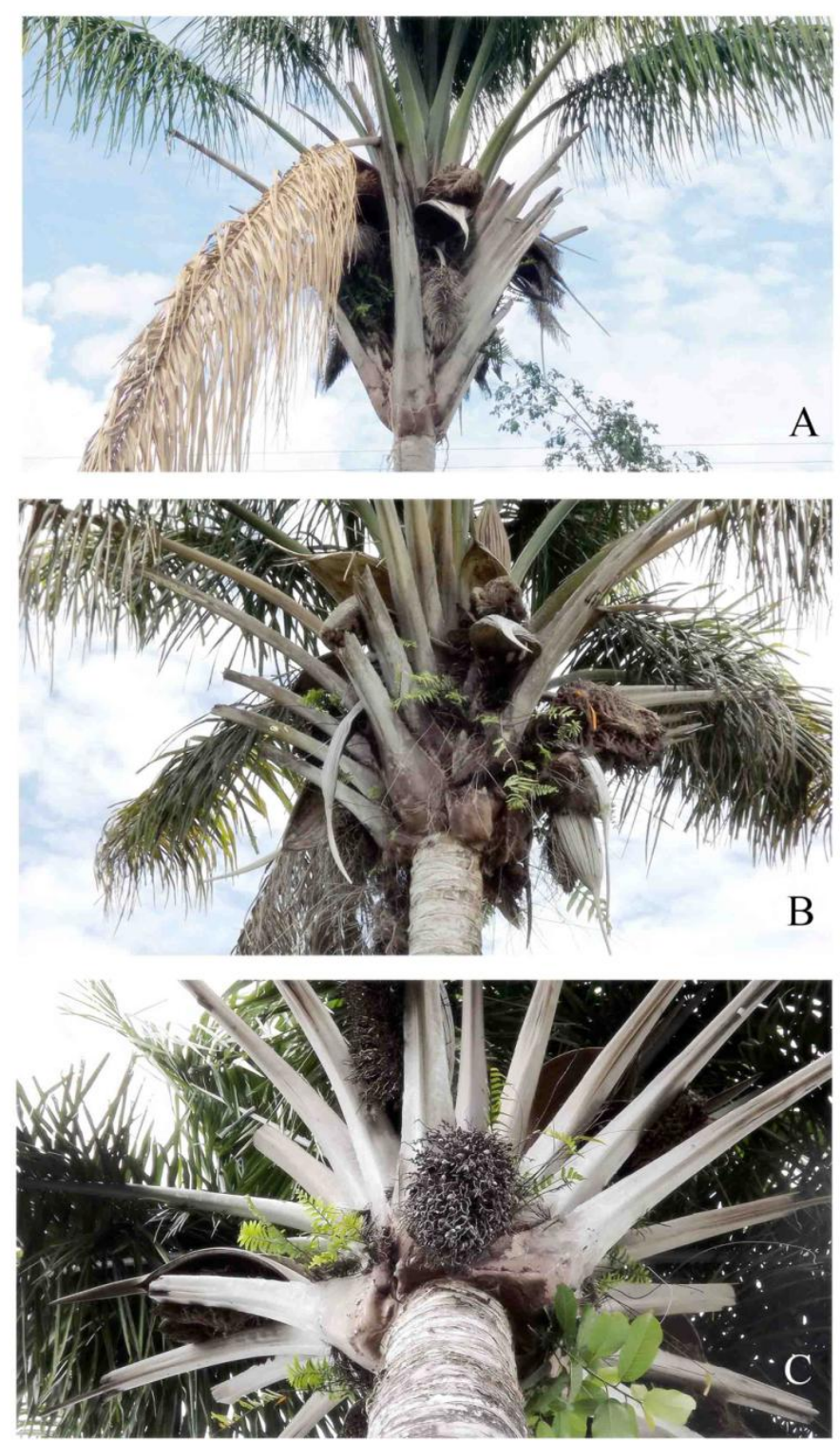

Figure 2. Attalea maripa foliar arrangement. (A) Columnar foliar insertion - M1, (B) Semi-spiraled foliar insertion - M2, and (C) Spiraled foliar insertion - M3

Foliar segments are constituted by straight pinnae, hanging from older leaves, distributed individually or grouped in 2, 3, 4 or 5 pinnae, which may be arranged regularly forming linear rows (Figure 3A) or irregularly at different angles (Figure 3B). 

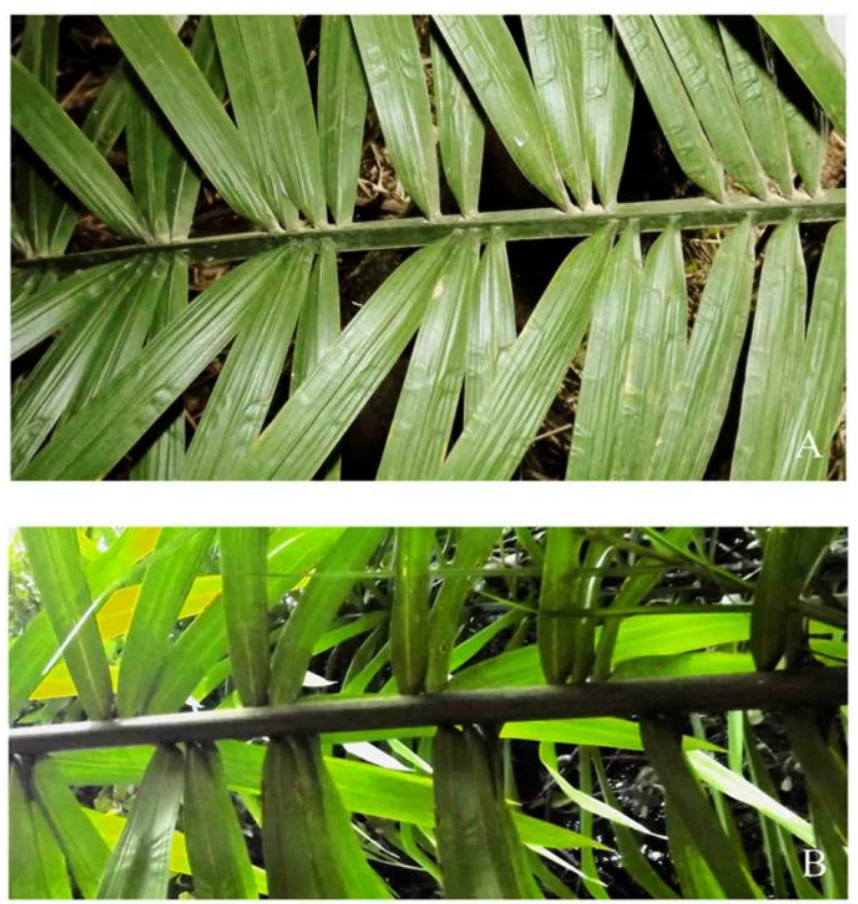

Figure 3. (A) Attalea maripa leaves with foliar segments arranged in regular planes distributed individually or grouped in 2, 3, 4 or 5 pinnae on one leaf; (B) Attalea maripa leaf with foliar segments irregularly inserted in different planes in groups of 2 or 3 pinnae

Usually the inajá leaf petiole presents irregular shape on leaf apex showing a concave shape with slight rippling on the median portion as it gets closer to foliar base. The lateral margins are smooth and extremely sharp forming persistent sheaths that remain attached to the stem even after the leaves fall off.

The maximum and minimum number of bunches observed on the three morphotypes was 5 and 1, respectively, with no significant statistical difference observed on the mean number of bunches between the three morphotypes $(\mathrm{p}=0.364)$. The maximum and minimum fruit lengths were 61.91 and $37.62 \mathrm{~mm}$, respectively, with no significant statistical difference observed on the mean length of the fruits found on the three identified morphotypes $(\mathrm{p}=0.173)$.

The maximum and minimum fruit diameter was $35.77 \mathrm{~mm}$ and $23.25 \mathrm{~mm}$ respectively, with a significant statistical difference verified on the mean diameter of the fruits analyzed on the three morphotypes $(p=0.012)$, with morphotype M2 being in average $2.34 \mathrm{~mm}$ wider than morphotype M3 $(\mathrm{p}=0.010)$.

The weight of the fruits ranged from $13.28 \mathrm{~g}$ to $36.63 \mathrm{~g}$. the mean weight of the fruits exhibited a significant statistical difference between the three morphotypes $(\mathrm{p}=0.011)$, being M2 $3,83 \mathrm{~g}$ heavier than $\mathrm{M} 3(\mathrm{p}=0.011)$.

The weight of the seeds varied from $6.86 \mathrm{~g}$ to $17.33 \mathrm{~g}$ with a significant statistical difference on the mean weight of the seeds between the analyzed morphotypes. Morphotype M2 seed is $1.99 \mathrm{~g}$ heavier than M3 and $1.581 \mathrm{~g}$ heavier than M1 ( $p=0.001$ and 0.024 respectively). Thus, M2 morphotype shows the highest values for most parameters analyzed, mainly in regard to the size, weight of fruits and seeds (diaspores), which may be positive for oil extraction, since it is extracted from the seed's mesocarp.

Attalea maripa inflorescence is intra-foliar and during this work, three inflorescence types were recorded: predominantly female, predominantly male and androgynous. During the collection of fruit-bearing bundles for morphometric analyses, we found a higher frequency of frutescence originating from predominantly female inflorescences.

The A. maripa fruits are smooth and oblong ellipsoid-shaped, presenting epicarp with a coloring that varies from light green to dark brown with or without the presence of ferruginous indumentum regardless their maturity stage (Figure 4). 

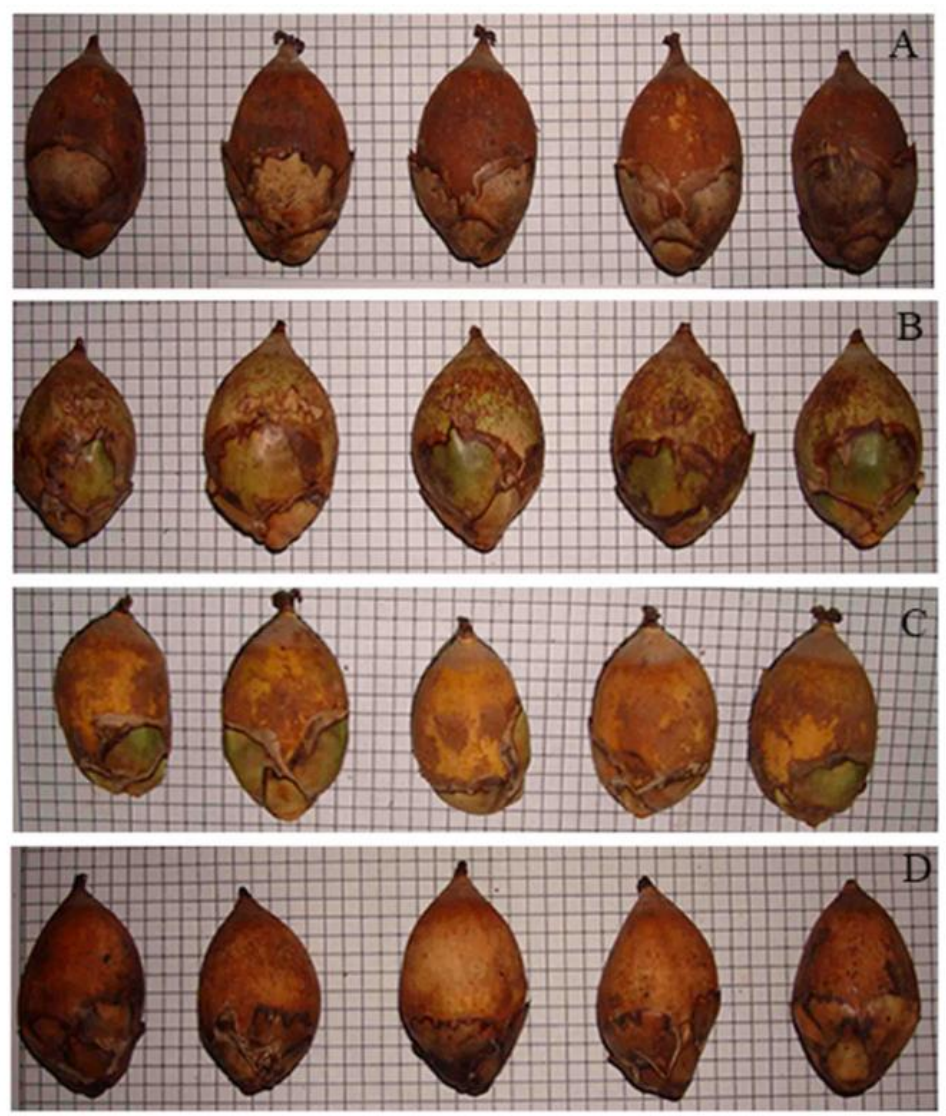

Figure 4. Attalea maripa ripe fruit epicarp coloring: (A) dark brown, (B) light green, (C) yellow with a ferrugineous tegument and (D) light brown

We also verified variability on the already ripe fruit mesocarp coloring, such as: light beige, pale yellow, yellow and live yellow or light orange (Figures 5A-5D) regardless the fruits' maturity stage.

Moreover, we detected some bunches where the fruits presented a sweet- tasting mesocarp without the characteristic saponaceous flavor occurring in the large majority of the studied individuals. We observed this trait on all mesocarp colorings.

The diaspores (endocarp + seeds) of inajá exhibit brown coloring and oblong ellipsoid shape which varies mainly in size. The endocarp is hard, flat and adhered to the kernel's tegument, with three holes protected by an operculum from where the seedling emerges. The interior of the diaspore is formed by cavities of ovarian unilocular, bilocular or trilocular origin, which shelter the kernels, of oblong shape of hard, solid and oily consistency constituted by white endosperm that fills practically all the interior of the locule where they lay (Figure 5E).

Even with the great difficulty of breaking the diaspores due to the pressure brought about by the nutcracker, it was possible to ascertain that $45.97 \%$ of the diaspores held one kernel; $35.63 \%$ two and $18.39 \%$ three kernels. The number of kernels equals that of the locule in $99 \%$ of the diaspores analyzed, since some locule were empty or with completely parched kernels (around 1.66\%). 

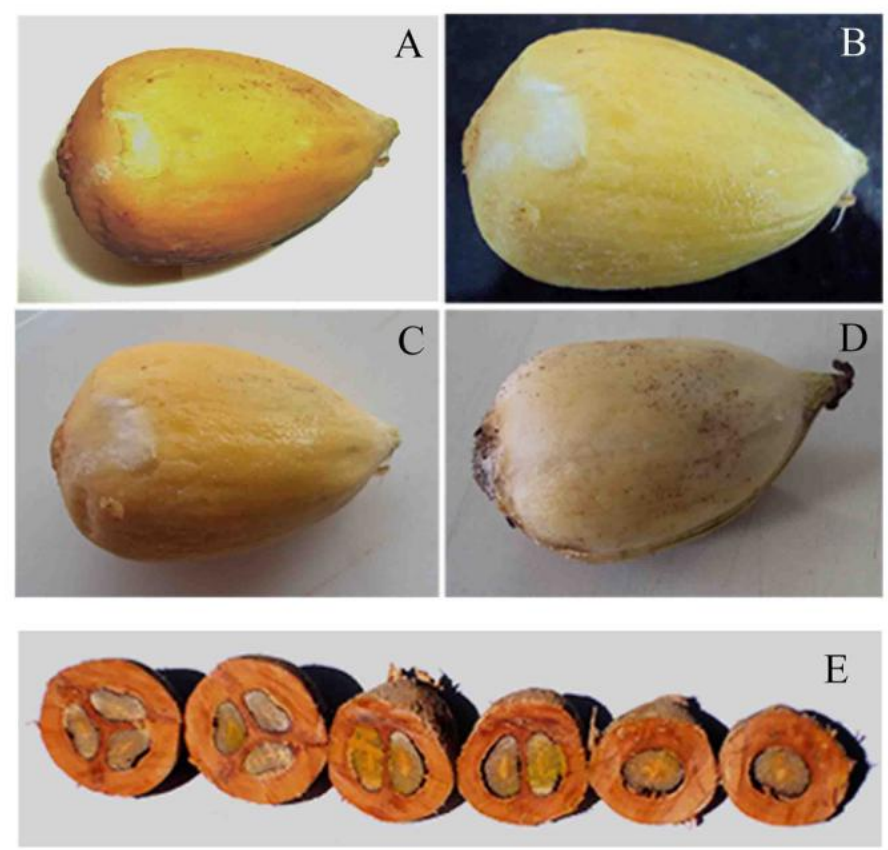

Figure 5. Attalea maripa fruits presenting varying mesocarp colorings: (A) yellow orange, (B) pale yellow, (C) yellow and (D) light beige. (E) Diaspores of M. maripa cut horizontally, constituted by one, two or three kernels

The linear correlation analysis between the morphometric parameters of the fruit (total weight, length and diameter) revealed a linear and positive correlation, between weight and diameter on the fruits originating from matrices with morphotypes M1, M2 and M3. Also, morphotype 2 presented positive correlation between the fruits' length and weight (Table 2).

Table 2. Correlation analysis of inajá fruits morphotypes physical characteristics identified in the state of Roraima

\begin{tabular}{ccccc}
\hline \multirow{2}{*}{ Morphotypes } & & \multicolumn{3}{c}{ Characteristics } \\
\cline { 3 - 5 } & & Length (L) & Diameter (D) & Weight (W) \\
\hline \multirow{3}{*}{ Columnar } & L & 1.00 & 0.32 & 0.33 \\
& $\mathrm{D}$ & 0.32 & 1.00 & $\mathbf{0 . 8 4}$ \\
& $\mathrm{W}$ & 0.33 & $\mathbf{0 . 8 4}$ & 1.00 \\
\hline \multirow{3}{*}{ Semi-spiraled } & $\mathrm{L}$ & 1.00 & 0.13 & 0.26 \\
& $\mathrm{D}$ & 0.13 & 1.00 & $\mathbf{0 . 8 3}$ \\
& $\mathrm{W}$ & 0.26 & $\mathbf{0 . 8 3}$ & 1.00 \\
\hline \multirow{3}{*}{ Spiraled } & $\mathrm{L}$ & 1.00 & 0.33 & $\mathbf{0 . 7 1}$ \\
& $\mathrm{D}$ & 0.33 & 1.00 & $\mathbf{0 . 6 8}$ \\
& $\mathrm{W}$ & $\mathbf{0 . 7 1}$ & $\mathbf{0 . 6 8}$ & 1.00 \\
\hline
\end{tabular}

Correlation values in bold are significant at the $5 \%$ confidence level.

\section{Discussion}

The seedling morphological descriptions found in A. maripa in this work, are similar to what was described in the palm tree Astrocaryum aculeatum Meyer (tucumã) by Gentil and Ferreira (2005), Archontophoenix alexandrae (F. Mueller) H. Wendl. and Drude by Charlo et al. (2006) and in the genera Phoenix and Orbignya by Tomlinson (1990). Moreover, one may also classify the A. maripa seedling emergence as remote aligulate or 
tubular, due to the marked lengthening of the cotyledon petiole and sheath and the absence of the ligule, just as described by Fabrício (2010) in the same species, in Syagrus oleracea (Mart.) Becc by Batista (2009), in Phoenix roebelenii by Iossi (2002) and in Caryotaurens L. by Pimenta (2007).

Henderson et al. (1995) includes A. maripa in the genus Attalea sensu lato, which seedlings are recognized by the lanceolate first eophyll with dentate upper margin, followed by one pinna of asymmetric apex with a brownish lateral protuberance on the abaxial side according to the descriptions made by Pintaud (2008). The morphology of the seedlings analyzed in this work differs from the one described by Pintaud (2008), thus it is advisable to place it under Maximiliana.

Regarding the A. maripa matrices characterization, Ferreira (2005) describes the arrangement of the leaves in a spiral for the inajá palm trees studied in the Acre state. Ribeiro et al. (1999), in a floristic survey carried out in the Reserva Ducke in the Amazon, refers to foliar insertion in five vertical rows. In the field observations made while developing the present study, we identified three inajá morphotypes, based on the insertion of the leaves into the apex of the stipe: columnar insertion (morphotype M1), semi-spiraled insertion (morphotype M2) and spiraled insertion (morphotype M3). The lack of recognition of different morphotypes in earlier studies might have been due either to the observation effort or the populations' uniformity in different regions, there being a need to carry out further studies for comparing such factors.

Morphotype M1 presents its leaves inserted with their foliar bases totally overlapped forming vertical columns, just as what that observed by Ribeiro et al. (1999). Morphotype M2 exhibits leaves inserted with their bases partially overlapped forming a column slightly curved on its median portion. Morphotype M3 presents its leaves inserted with their bases barely or not overlapped in a spiral, like that observed by Ferreira (2005).

In most A. maripa descriptions, the pinnae of the leaves are described as straight, erect, grouped and arranged in different angles (Henderson, 1995; Ribeiro et al., 1999). Lorenzi (2010) describes the pinnae as inserted in diverse planes giving the leaves a feathery look. In the three morphotypes here described, the segments are either arranged regularly forming linear rows or irregularly in different angles.

DBH mean values found in individuals of $A$. maripa studied in Roraima revealed values lower those recorded in literature as in the works of Miranda and Rabelo (2006) where the authors report a DBH of $40 \mathrm{~cm}$ for individuals situated in an urban forest patch in the city of Manaus.

In all morphotypes observed the infrutescence resulting from predominantly female inflorescences showed to be the most frequent, differing from the results found by Duarte (2008), where the author reports that throughout 2007 the highest incidence was that of bundles coming from predominantly male inflorescences. As in the present study, the presence of androgynous and predominantly female inflorescences was also reported by the same author. In addition to the above related inflorescence and bunch types, Cravo (1998) also recorded exclusively male inflorescences, which was not detected throughout the collection of data for this study.

The inflorescence of the three morphotypes studied is intra-leaf, corroborating descriptions by Matos (2010) and Duarte (2008). These observations are different from those reported by Cravo (1998) and Miranda et al. (2001), who reported the inflorescence as inter-leaf type. These misunderstanding might be have occurred due to the difficulty to reach the crown of A. maripa creating doubts on the observer on what pertained to the insertion of the bunches, since they are arranged between the columns, when observed from below. It is important to highlight that one advantage of the arrangement of the bunches between the columns of the leaves in morphotypes M1 and M2 would be the easier fruit handling and harvesting.

Attalea maripa fruits are oblong, ellipsoid- shaped and flat, exhibiting a coloration that varies from light green to dark brown with or without the presence of ferruginous indumentum regardless their maturity degree. The mesocarp exhibited colorations such as: light beige, light yellow, yellow and orange in ripe fruits and, as in the epicarp, coloration was not dependent on the fruits' maturity degree.

Regarding the fruits, we observed a wide variability on the colors of the epicarp (shell) of the already ripe fruits, varying from light green shades to yellow to dark brown with or without the presence of ferruginous indumentum in all coloration varieties regardless the maturity degree. Araújo et al. (2000) describe, for the fruits of inajá, the coloring of the indumentum as ferruginous almost on the whole fruit and whitish on the apical region. Duarte (2008) mentions the inajá fruit coloring to vary from green to dark brown, with or without the presence of the indumentum, of predominantly ferruginous color.

According to Blaak (1983) the immature fruits throughout the ripening process and, those already ripen, exhibit shell green, yellowish-green and brownish-yellow, according to the fruits' maturity degree. However, during this study we found Green-shelled ripe fruits, so it wasn't possible to infer such associations with the maturity of 
fruits.

Likewise, variation in mesocarp coloring was not related to the fruit's maturation. Araújo et al. (2000) describe the coloring of the mesocarp as being light beige, light yellow and toasted yellow, in this order, according to the fruit's maturation.

Some bunches bearing ripe fruits of inajá regardless the coloring of the mesocarp, presented sweet and not saponaceous flavor, contradicting Duarte (2008), where he reports the ripe fruits with green or greenish shell to normally present light beige mesocarp and sweeter flavor.

Regarding the number of kernels, the diaspores holding one or two kernels were more frequent, corroborating what was observed by Araújo et al. (2000) and Duarte (2008) for the same species.

The linear correlation analysis between the morphometric parameters revealed a high linear and positive correlation between the weight and diameter in the fruits resulting from matrices with morphotypes M1, M2 and M3. Also, morphotype M2 presented positive correlation between the length and the weight of the fruits. According to Kuniyoshi (1993), the fruits and seeds' morphometric and morphological characteristics may vary from one place to another and between trees.

Thus, even though the semi-spiraled morphotype presented the highest positive correlation between the length and the weight of the fruits, there was a positive correlation between the diameter and the weight in all the analyzed morphotypes. This data resembles that found by Matos (2010) when studying the morphometry of the fruits in inajá populations in two areas where the species occurred in the Pará State, where the highest correlations occurred between the length and weight of the fruits, as well.

\section{Conclusion}

The findings pertaining to the morphometric variables observed during the present study suggest that the semi-spiraled morphotype (M2) is likely to be an intermediate form of a widely variable character within $A$. maripa.

\section{References}

Araújo, M. G. P., Leitão, A. M., \& Mendonça, M. S. (2000). Morfologia do Fruto e da semente de Inajá (Attalea Maripa (Aubl.) Mart.) - Palma. Rev Bras Sementes, 22, 31-38.

Batista, G. S. (2009). Morfologia e Germinação de Sementes de Syagrus Oleracea (Mart.) Becc (Arecaceae) (Unpublished doctoral dissertation). Universidade Estadual de São Paulo, São Paulo, Brasil.

Bezerra, V. S. (2011). O Inajá (Maximiliana maripa (Aubl.) Drude) como fonte alimentar e oleaginosa (Comunicado Técnico, 129). Macapá, Embrapa.

Blaak, G. (1983). Processamiento de los frutos de la palmera Cucurita (Maximiliana maripa). In United Nations. Food and Agriculture Organization (Ed.) Palmeras poco utilizadas de América Tropical: Reunion: Reports (pp.113-117). Turrialba, Costa Rica: FAO/CATIE.

Ministério da Agricultura. (1992). Regras para análise de sementes. Brasilia, DF: Departamento Nacional de Produção Vegetal.

Cavalcante, P. B. (1991). Frutas comestíveis da Amazônia (5th ed.). Belém, PA: Museu Paraense Emílio Goeldi.

Charlo, H. C., Môro, F. V., Silva, V. L., Silva, B. M., Bianco, S., \& Môro, J. R. (2006). Aspectos morfológicos, germinação e desenvolvimento inicial de plântulas de Archontophoenix alexandrae (F. Mueller) H. Wendl. e Drude (Arecaceae) em diferentes substratos. Rev Árvore, 30, 933-940. http://dx.doi.org/10.1590/S0100-67622006000600008

Cravo, M. J. (1998). Estudo de Parâmetros palinológicos e aspectos ecológicos do Inajá, Maximiliana maripa (Aublet) Drude (palmae), em área conservada e áreas desmatadas da Amazônia (unpublished master's thesis). Instituto Nacional de Pesquisas da Amazônia/Fundação Universidade do Amazonas, Manaus, Brazil.

Duarte, O. R. (2008). Avaliação quantitativa e análise dos parâmetros biológicos, químicos e fisicico-químicos de frutos de Maximiliana maripa (Aubl.) Drude (inajá) como subsidio ao estudo do potencial oleifero de populações promissoras para o estado de Roraima (unpublished doctoral dissertation). Instituto Nacional de Pesquisas da Amazônia, Manaus, Brazil.

Fabrício, C. B. (2010). Aspectos fisiológicos e bioquímicos da germinação da semente de inajá (maximiliana maripa (Aublet) Drude) (unpublished master's thesis). Instituto Nacional de Pesquisas da Amazônia, 
Manaus, Brazil.

Ferreira, E. L. (2005). Manual das Palmeiras do Acre, Brasil. Retrieved from http://www.nybg.org/bsci/acre/www1/manual_palmeiras.html

Gentil, D. F., \& Ferreira, S. A. (2005). Morfologia da plântula em desenvolvimento de Astrocaryum aculeatum Meyer (Arecaceae). Acta Amazonica, 35, 337-342. http://dx.doi.org/10.1590/S0044-59672005000300005

Henderson, A. (1995). The Palms of the Amazon. New York: Oxford University Press.

Henderson, A., Galeano, G., \& Rodrigo, B. (1995). A field guide to the palms of the Americas. New Jersey: Princeton University Press.

Iossi, E. (2002). Morfologia e germinação de sementes de tamareira-anã (Phoenix roebelenii O’ Brien) (unpublished master's thesis). Universidade Estadual Paulista, Jaboticabal, Brazil.

Kahn, F. (1990). Clave para diferenciar los géneros de palmae en la Amazonia a partir del aparato vegetativo. Bull. Inst. Fr.Etudes andin., 19, 351-378.

Kerbauy, G. B. (2008). Fisiologia Vegetal (2nd ed.). Rio de Janeiro, RJ: Guanabara.

Köppen, W. (1984). Climatologia - con un estudio de los climas de la tierra. México: Fondo de Cultura Econômica.

Kuniyoshi, Y. S. (1993). Aspectos morfo-anatômicos do caule, raiz e folha de Tabebuia cassinoides (Lam.) DC. (Bignoniaceae) em diferentes fases sucessionais no litoral do Paraná (unpublished master's thesis). Universidade Federal do Paraná, Curitiba, Brazil.

Lorenzi, H. (2010). Flora brasileira: Arecaceae (palmeiras). São Paulo, SP: Instituto Plantarum.

Matos, A. (2010). Biometria e Morfologia de Attalea Maripa (Aubl.) Mart. (Inajá) em Sistema Silvipastoril o Nordeste Paraense (unpublished master's thesis). Universidade Federal Rural da Amazônia, Belém, Brazil.

Miranda, I. P., Rabelo, A., Bueno, C. R., Barbosa, E. M., \& Ribeiro, M. N. (2001). Frutos de palmeiras da Amazônia. Manaus, AM: MCT/INPA.

Miranda, I. P., \& Rabelo, A. (2006). Guia de Identificação das Palmeiras de um Fragmento Florestal Urbano. Manaus-AM: EDUA/INPA.

Pereira, A. S., Alves, H. P., Sousa, C. M., \& Costa, G. L. (2013). Prospecção sobre o conhecimento de espécies Amazônicas - inajá (Maximiliana maripa Aublt.) e bacaba (Oenocarpus bacaba Mart.). Revista Geintec, 3, 110-122. http://dx.doi.org/10.7198/S2237-0722201300020009

Pintaud, J. C. (2008). An overview of the taxonomy of Attalea (Arecaceae). Rev. Peru. Biol., 15, 55-63.

Pimenta, R. S. (2007). Morfologia e germinação de sementes de Caryota urens (Lam.) Mart. (Arecaceae) (unpublished master's thesis). Universidade Estadual Paulista, Jaboticabal, Brazil.

Ribeiro, J. E., Hopkins, M. J., Vicentini, A., Sothers, C. A., Costa, M. A., Brito, J. M., .. Procópio, L. C. (1999). Flora da Reserva Ducke. Guia de identificação das plantas vasculares de uma floresta de terra firme na Amazônia Central. Manaus, AM: INPA-DFID.

Salm, R. (2005). The importance of forest disturbance for the recruitment of the large arborescent palm Attalea maripa in a seasonally-dry Amazonian forest. Biota neotrop., 5, 1-6. http://dx.doi.org/10.1590/S1676-06032005000300011

Tomlinson, P. B. (1990). The structural biology of palms. Oxford: Clarendon Press.

\section{Copyrights}

Copyright for this article is retained by the author(s), with first publication rights granted to the journal.

This is an open-access article distributed under the terms and conditions of the Creative Commons Attribution license (http://creativecommons.org/licenses/by/3.0/). 